\title{
Evaluation and Utilization of Defatted Tiger Nut (Cyperus esculentus L.) Flour in Preparation of Some Drinks and Food Products
}

\author{
Reda A. Aamer \\ Hort. Crop Technology Res. Department, Food Technology Research Institute, A.R.C., Egypt
}

Received: 22 March, 2019

Revised: 23 April, 2019

Accepted: 5 May, 2019

\begin{abstract}
Full-fat and defatted tiger nut (Cyperus esculentus L.) flours (FFTF and DFTF) were analyzed in terms of proximate chemical composition, physical and functional properties and minerals content. The amino acid composition of DFTF was also determined. Moreover, the fatty acid composition of tiger nut oil was analyzed. Vegan milk drinks with different flavouring agents (cinnamon, ginger, vanilla, coconut, lemon and chocolate), pudding and creamy onion soup were prepared using DFTF and their sensory qualities were evaluated. The results showed that FFTF contained a high amount of oil $(28.52 \%)$ in which oleic acid was the predominant fatty acid. The oil is considered as a highly healthy oil and can be used as a good source of edible vegetable oil. The DFTF contained high amounts of nitrogenfree extract $(78.11 \%)$, starch $(45.85 \%)$, dietary fiber $(22.69 \%)$, total and non-reducing sugars $(23.56 \%$ and $20.39 \%$ respectively), as well as fairly good amounts of essential amino acids and certain minerals which indicated its high nutritional value. The organoleptic properties of vegan milk drinks, pudding and creamy onion soup prepared from DFTF showed acceptable good sensory quality.
\end{abstract}

Key words: Tiger nut tubers, defatted flour, amino acids, fatty acids, vegan milk drinks, pudding, creamy onion soup.

\section{INTRODUCTION}

Tiger nut (Cyperus esculentus L.) is one of numerous underutilized crops. According to Oladele \& Aina (2007), such crops deserve investigation to reveal their productivity and nutritive value. Notwithstanding, the price and the world demand for vegetable oils are increasing yearly. Countries which have no conventional seed oils should carry out studies which could lead to commercial production of new seed oils to at least satisfying local demand (Olagunju, 2006).

Food processing by-products may still contain many important components like pigments, organic acids, dietary fiber, flavours, and antibacterial or antifungal substances (Fernández- López et al., 2008, Ku \& Mun 2008). It has been proven that many of these compounds possess health benefits. These by-products can be modified into ingredients for new products.

Though the tiger nut cultivation dates returned to ancient Egypt, where tubers were found in sarcophagi and tombs of the earliest dynasties, it's for the most part untapped (Anon, 2013). Tiger nut (Cyperus esculentus) belongs to the family Cyperaceae and is commonly known as earth nut, earth almond due to its almond like flavour, Chufa (in Spain), Hab-el-Aziz (in Egypt), yellow nut, rush nut sedge and Zulu nuts (in Nigeria ) according to Mosquera et al. (1996) and Cantalejo (1997).

Tiger nut is widely used for human consumption and animal feed. In Egypt, it is used as a source of food, medicine and perfumes (Imam et al., 2013). It is usually used after soaking in water or roasted before being eaten, also it's habitually consumed by nursing mothers. Dried ground tubers are used in chocolate, coffee and biscuits. It is also used for the production of candy, jam, nougat, beer and as a flavouring agent in ice cream. The successful use of chufa tubers as a flavouring agent is considered with reference to nut roasting, ice cream formulation and other applications such as biscuits and other similar products such as coffee substitute (Cantalejo, 1997). In Spain, these tubers are fundamentally used to make a milk-like beverage known as the "Horchata de chufa" the beverage is a nonalcoholic refreshing drink of dairy appearance and is generally consumed in summer-time (Mosquera et al., 1996). The beverage was initially prepared by Muslims and now is common in Spain and numerous different European and Latin-American countries (Cortés et al., 2005). 
Tiger nut had been mentioned to be a "health" food, since its consumption will facilitate to forestall cardiovascular disease and occlusion and is claimed to activate blood circulation (Chukwuma et al., 2010). It absolutely was additionally found to help in reducing the chance of carcinoma (Adejuyitan et al., 2009). These tubers also have been reported to be aphrodisiac, carminative, diuretic, emmenagogue, stimulant and tonic (Chopra et al., 1986 \& Chevallier, 1996), indigestion, diarrhoea, dysentery, and excessive thirst (Chevallier, 1996). These tubers are rich in calories content (fat, protein, starch and sugar), minerals (specifically phosphorus and potassium), and vitamins E and C (Belewu \& Belewu 2007), further, tiger nut has been verified to contain higher essential amino acids than those proposed in the protein standard by the FAO/WHO (1985).

It is worth to mention that there is a limited published work about tiger nut oil and defatted tiger nut flour. Accordingly, the present study was aimed to evaluate such components from the nutritional point of view along with its use to formulate some food products and drinks.

\section{MATERIALS AND METHODS}

\section{Materials:}

Tiger nut (Cyperus esculentus L.) tubers were obtained from the local market in Alexandria, Egypt. All chemicals and reagents used in this study were purchased from El-Gomhouria Co. for Chemical and Medical Products. Other ingredients including wheat flour ( $72 \%$ extraction), sugar, salt, corn starch, liquid milk, onion, butter, white pepper, cinnamon, freshly grated ginger, vanilla, coconut, lemon and chocolate cocoa powder were obtained from Alexandria markets, Egypt.

\section{Methods:}

\section{Preparation of full and defatted flours from tiger nut tubers}

Full-fat (FFTF) and defatted flours of tiger nut (DFTF) were prepared as described in Fig. (1). Tiger nut tubers were cleaned, washed with tap water and then rinsed, drained and air dried at $40^{\circ} \mathrm{C} / 8 \mathrm{hr}$ before being stored in glass jars at $4^{\circ} \mathrm{C}$ until used. A portion of the dried tubers was ground with a stainless steel grinder ( $\mathrm{Sf}$ stardust, model: Cml-600 mkii, JAPAN) to obtain full-fat tiger nut flour (FFTF) and stored in glass jars at $4^{\circ} \mathrm{C}$ until

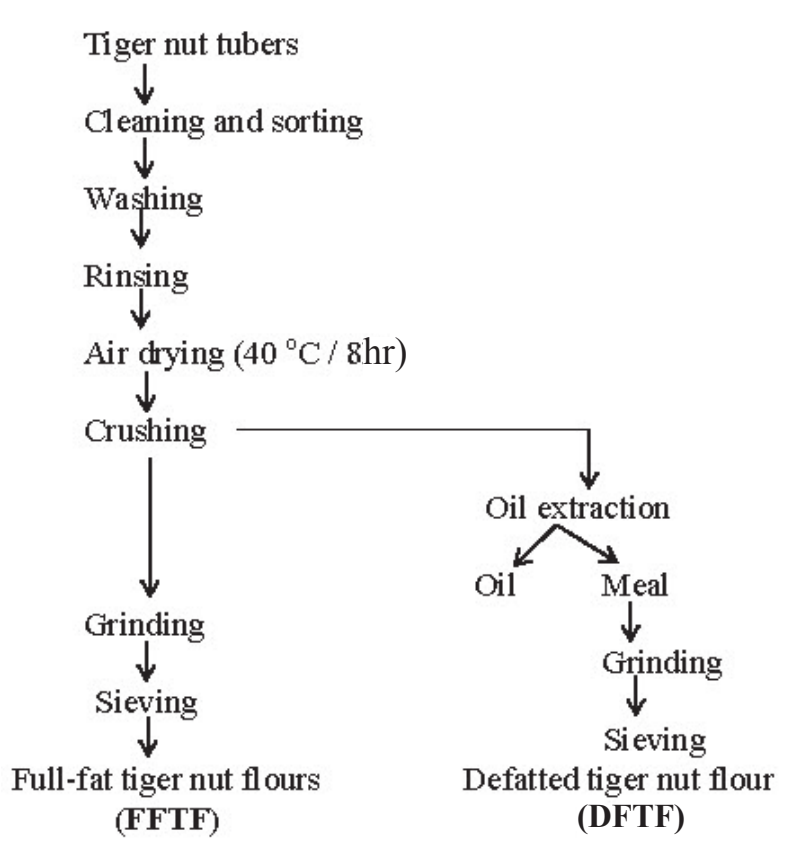

Fig. 1: Flow sheet illustrating the preparation of full-fat and defatted tiger nut flours.

analyzed. Another portion of the full-fat tiger nut tubers was crushed and pressed by a hydraulic laboratory press. The extracted oil was dried over anhydrous sodium sulphate, filtered through Whatman No. 1 filter paper and kept in brown bottles at $-18^{\circ} \mathrm{C}$ until analyzed for fatty acids. The remaining meal after oil extraction was re-extracted by Soxhlet extractor using hexane at $60-80^{\circ} \mathrm{C}$ according to the AOAC (2005). After defatting, the meal was passed through 60 mesh sieve. The resultant flour was stored in a glass jar at $4^{\circ} \mathrm{C}$ until used.

\section{Physical properties}

Seed index ( $\mathrm{g} / 100$ tuber) was determined as outlined by Abdel-Nabey (2001). The bulk density of FFTF and DFTF was carried out according to Narayana \& Narasinga (1992).

\section{Chemical methods}

Proximate chemical composition of FFTF and DFTF including moisture, crude ether extract, crude protein, crude fiber and total ash were determined as described in the AOAC (2005). Nitrogen free extract was calculated by difference. Reducing and total sugars were estimated by the Lane- Eynon procedure as stated in the AOAC (2005) Non-reducing sugars were calculated by difference using the factor 0.95 (AOAC, 2005). Starch was determined according to the AOAC method (2005). Total dietary fiber was estimated as reported by Prosky et al. (1985). Energy value was calculated using the universally 
accepted conversion factors by multiplying protein and carbohydrates by 4.00 and fat by $9.00 \mathrm{Kcal} / \mathrm{g}$.

\section{Determination of minerals}

Minerals including $\mathrm{Ca}, \mathrm{Mg}, \mathrm{Fe}$ and $\mathrm{Zn}$ were determined as described in the AOAC (2005) using Perkin Elmer Atomic Absorption Spectrophotometer (Model 2380, Japan), Na and K were determined using Flame Photometer (model PE P7, England), as described in the AOAC (2005).

\section{Fatty acid composition}

Fatty acid composition was analyzed by Gas Liquid Chromatography (GLC). The oil was esterified before GLC analysis using the method described by Stahle (1967). The chromatogram of the authentic fatty acids was used to characterize the fatty acids according to their retention times. Fatty acid composition was expressed as a percentage of the total fatty acids (Farag et al., 1984).

\section{Amino acid composition}

Amino acid composition of DFTF was analyzed according to the method of the AOAC (2005). Amino acids were performed in the hydrolyzate using Amino Acid Analyzer (Biochrom 30). Amino acid composition was expressed as $\mathrm{g} / 100 \mathrm{~g}$ protein.

\section{Functional Properties}

\section{Water and oil absorption capacities}

Water absorption capacity (WAC) and oil absorption capacity (OAC) of FFTF and DFTF were determined according to Sze-Tao \& Sathe (2000). The results were expressed as $g$ of water or oil held per $\mathrm{g}$ of flour sample.

\section{Least gelation concentration}

Least gelation concentration (LGC) was determined by the method of Sathe \& Salunkhe (1981).

\section{Technological methods}

\section{Preparation of vegan milk drinks}

The vegan milk drinks were prepared from DTF as shown in Fig. (2) as outlined by CRDO (2012) and Corrales et al. (2012) with some modifications. Mixing vegan milk drinks with different flavouring agents was done using a blender (Kenwood major titanium, Japan), each drink was assessed organoleptically while cold.

\section{Preparation of pudding}

Pudding was prepared by replacing corn starch with $0,25,50,75$ and $100 \%$ DFTF according to the method described by Abdel-Hady (1998). The formula used for preparing pudding is shown in Table (1).

\section{Preparation of creamy onion soup}

Creamy onion soup was prepared by replacing wheat flour ( $72 \%$ extraction) with $0,25,50,75$, and $100 \%$ DTF according to the method described by Raymond \& James (1970). The formula used for preparing creamy onion soup is shown in Table (1).

\section{Sensory evaluation}

Sensory evaluation of the defatted tiger nut milk drinks, pudding and creamy onion soup were assessed by 10 panelists of the Food Technol. Lab., Food Technol. Research Inst., Agricultural Research Center, of Sabahia, Alexandria, Egypt. The panelists were asked to evaluate the samples by scoring the following attributes: Colour, taste, odour, texture and overall acceptability according to a standard hedonic rating scale from 9 (like extremely) to 1 (dislike extremely) according to Kramer \& Twigg (1973).

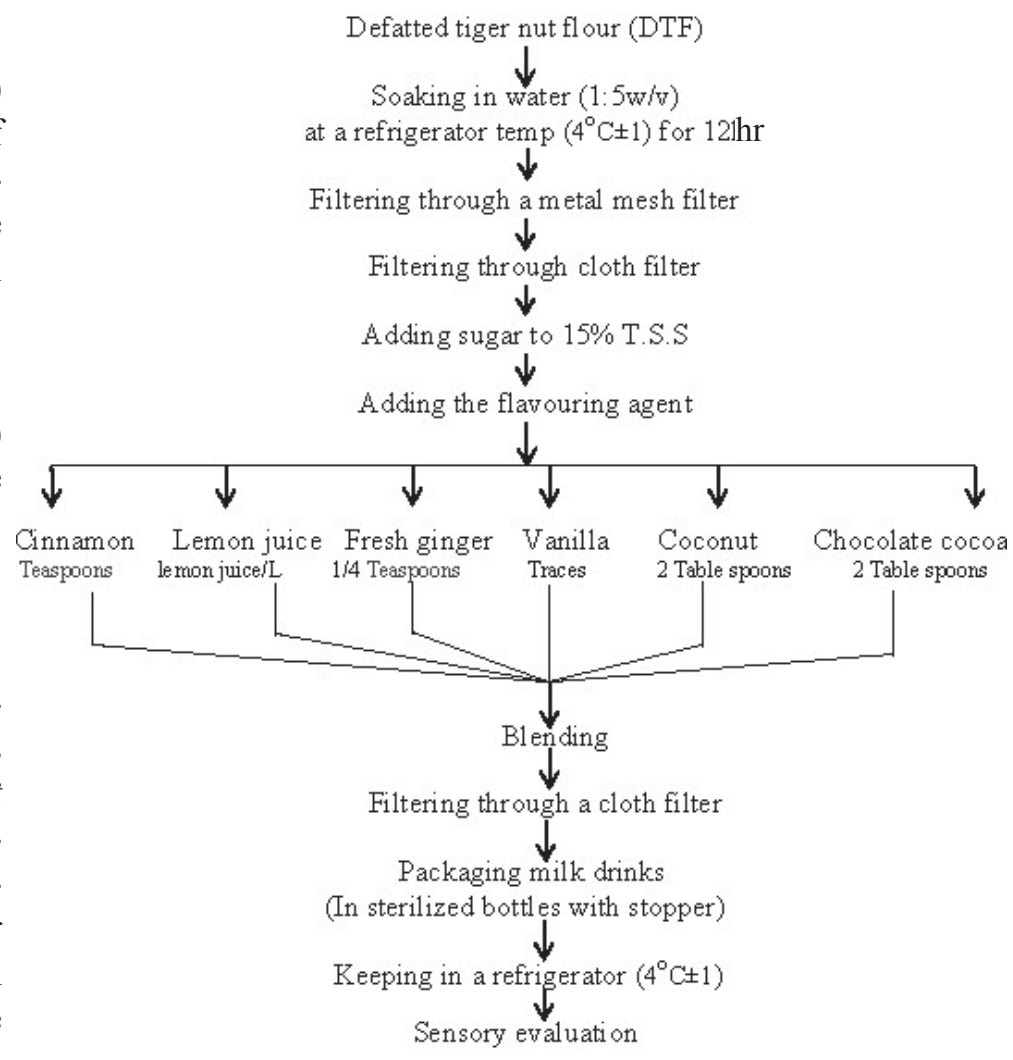

Fig 2: Flow sheet for tiger nut milk drinks production 
Table 1: Ingredients used for the preparation of pudding and creamy onion soup.

\begin{tabular}{|c|c|c|c|c|c|c|c|c|c|c|}
\hline \multirow{3}{*}{ Ingredients } & \multicolumn{5}{|c|}{ Pudding } & \multicolumn{5}{|c|}{ Creamy onion soup } \\
\hline & \multicolumn{5}{|c|}{ DFTF* $(\%)$} & \multicolumn{5}{|c|}{ DFTF* (\%) } \\
\hline & 0 & 25 & 50 & 75 & 100 & 0 & 25 & 50 & 75 & 100 \\
\hline Corn starch (g) & 25 & 18.75 & 12.5 & 6.25 & 0 & - & - & - & - & - \\
\hline $\mathrm{DTF}^{*}(\mathrm{~g})$ & 0 & 6.25 & 12.5 & 18.75 & 25 & 0 & 6.25 & 12.5 & 18.75 & 25 \\
\hline Wheat flour (g) & - & - & - & - & - & 25 & 18.75 & 12.5 & 6.25 & 0 \\
\hline Liquid milk (ml) & 400 & 400 & 400 & 400 & 400 & 180 & 180 & 180 & 180 & 180 \\
\hline Water (ml) & - & - & - & - & - & 500 & 500 & 500 & 500 & 500 \\
\hline Chopped onion (g) & - & - & - & - & - & 215 & 215 & 215 & 215 & 215 \\
\hline Butter (g) & - & - & - & - & - & 27 & 27 & 27 & 27 & 27 \\
\hline Salt (g) & - & - & - & - & - & 6 & 6 & 6 & 6 & 6 \\
\hline White pepper (g) & - & - & - & - & - & 0.19 & 0.19 & 0.19 & 0.19 & 0.19 \\
\hline
\end{tabular}

*(DFTF): Defatted tiger nut flour

\section{Statistical analysis}

All the analyses except minerals, amino and fatty acids were carried out in triplicates and expressed as mean and standard deviation (SD). Data of the organoleptic properties were subjected to analysis of variance using (ANOVA) and significant differences were identified by Duncan's Multiple Range test $(P<0.05)$ using SAS program software program (SAS Institute 2004).

\section{RESULTS AND DISCUSSION}

\section{Physical and chemical properties of FFTF and DFTF}

The average yield of tiger nut oil extraction was $28.52 \%$ for oil and $71.28 \%$ for the meal. As shown in Table (2), the seed index is $42.34 \mathrm{~g} / 100$ of full-fat tiger nut tubers, while the bulk density is 0.56 and $0.31 \mathrm{~g} / \mathrm{cm} 3$ for FFTF and DFTF, respectively. These results agreed well with Oladele \& Aina (2007) who mentioned that the bulk density of brown tiger nut flour was $0.55 \mathrm{~g} / \mathrm{cm} 3$. The FFTF was found to be a good source of oil being 28.52 $\%$. The oil content of tiger nut was found to vary in a range between 22.8 and $32.8 \mathrm{~g} / 100 \mathrm{~g}$ (Linssen et al., 1988, Temple et al., 1989 \& Coskuner et al., 2002).The DFTF contained high values of protein, ash, crude fiber, nitrogen free extract, total, reducing, non-reducing sugars, starch and total dietary fiber compared with FFTF. In general, FFTF and DFTF had high contents of starch and dietary fiber. Consequently, the FFTF and DFTF can be used as a good source of dietary fiber. The high content of starch and total sugars is an indicator for digestive character of the defatted flour and tubers utilized for vegan milk preparation (Chopra et al., 1986, Ejoh \& Ndjouenkeu, 2007). Also, Alegría-Torán \& Farré-Rovira (2003) reported that tiger nut had high content of dietary fiber which may be effective in the treatment and prevention of many diseases including coronary heart disease (Chukwuma et al., 2010), obesity, diabetes, gastrointestinal disorders (Anderson et al., 2009), colon cancer (Adejuyitan et al., 2009), and losing weight (Borges et al., 2008).

\section{Functional properties}

\section{Least gelation concentration}

The results of least gelation concentration (LGC) for FFTF and DFTF are presented in Fig. (3). The results showed that the LGC is 8 and 16 $\%$ for FFTF and DTF, respectively. Aditya (2012) stated that there is no direct relationship between

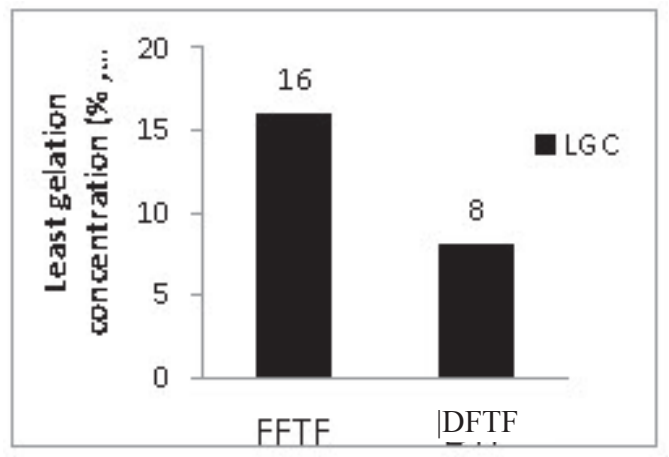

Fig. 3: Least gelation concentration of FFTF and DFTF 
Table 2: Physical properties and chemical composition of FFTF and DTF.

\begin{tabular}{lll}
\hline Physical properties and chemical composition & \multicolumn{1}{c}{ FFTF } & \multicolumn{1}{c}{ DFTF } \\
\hline Physical properties & & - \\
Seed index (g/100 tuber) & $42.34 \pm 3.76$ & --- \\
Bulk density (g/ cm $\left.{ }^{3}\right)$ & $0.56 \pm 0.032$ & $0.31 \pm 0.021$ \\
Chemical composition* (\%) & \\
Moisture & $9.32 \pm 0.57$ & $9.56 \pm 0.28$ \\
Crude ether extract & $28.52 \pm 0.85$ & --- \\
Crude protein & $4.52 \pm 0.22$ & $6.30 \pm 0.29$ \\
Crude fiber & $8.79 \pm 1.24$ & $12.20 \pm 0.22$ \\
Ash & $2.15 \pm 0.26$ & $3.39 \pm 0.08$ \\
Nitrogen free extract & $56.02 \pm 0.23$ & $78.11 \pm 0.21$ \\
Total sugars & $16.84 \pm 1.67$ & $23.56 \pm 1.32$ \\
Reducing sugars & $1.47 \pm 0.46$ & $2.10 \pm 0.89$ \\
Non-reducing sugars & $14.60 \pm 1.50$ & $20.39 \pm 0.64$ \\
Starch & $32.85 \pm 2.97$ & $45.85 \pm 1.86$ \\
Total dietary fiber & $16.28 \pm 0.83$ & $22.69 \pm 0.97$ \\
Energy value (Kcal /100g) & $498.84 \pm 0.43$ & $337.74 \pm 0.25$ \\
\hline
\end{tabular}

* Results are mean values \pm S.D on a dry weight basis

defatting and LGC as reported in some research LGC decreased after defatting while in other researchs it increased. LGC is an important in property food products requiring thickening and gelling agents such as puddings and sauces.

\section{Water and oil absorption capacities}

The results of water absorption capacity (WAC) and oil absorption capacity (OAC) for FFTF and DFTF are presented in Fig. (4). The WAC values of FFTF and DFTF are 1.2 and $2.8 \mathrm{ml} / \mathrm{g}$, respectively, This result is close to that found by Oladele \& Aina (2007) who found that WAC of two different varieties of tiger nut was 1.37 and $1.26 \mathrm{ml} / \mathrm{g}$, respectively. The OAC values of FFTF and DFTF is 1.8 and $2.1 \mathrm{ml} / \mathrm{g}$, respectively, as shown in Fig. (4).

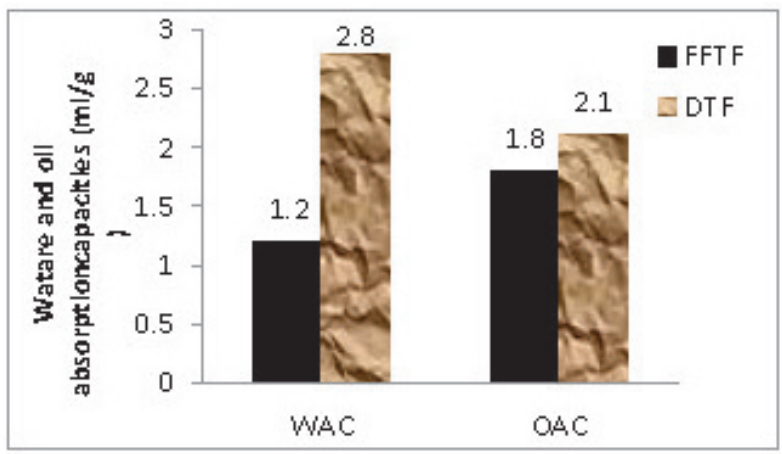

Fig. 4: Water and oil absorption capacities $(\mathrm{ml} / \mathrm{g})$ of FFTF and DFTF

\section{Mineral contents of FFTF and DFTF}

Mineral content of FFTF and DTF is given in Table (3). In general, the results indicated that the DFTF contained high amounts of all the tested minerals as compared with FFTF, it was obvious that $\mathrm{K}, \mathrm{Na}, \mathrm{Mg}, \mathrm{Ca}$ were the major minerals, while $\mathrm{Fe}$ and $\mathrm{Zn}$ were found in small concentrations. The aforementioned data are in accordance with those reported by Omode et al., (1995) and Abdel-Naby (2001). In general, FFTF and DFTF can be considered as a good source of $\mathrm{K}, \mathrm{Mg}, \mathrm{Na}$ and $\mathrm{Ca}$.

\section{Fatty acid composition of tiger nut oil}

The data in Table (4) show the fatty acid composition of tiger nut oil. It had a high amount of

Table 3: Mineral content of FFTF and DTF.

\begin{tabular}{lll}
\hline Element (mg/100g)* & FFTF & DFTF \\
\hline $\mathrm{K}$ & 728.93 & 964.76 \\
$\mathrm{Na}$ & 220.73 & 300.42 \\
$\mathrm{Ca}$ & 76.63 & 103.75 \\
$\mathrm{Mg}$ & 120.34 & 160.52 \\
$\mathrm{Fe}$ & 4.98 & 6.37 \\
$\mathrm{Zn}$ & 5.87 & 7.69 \\
\hline
\end{tabular}

* Data on dry weight basis 
Table 4: Fatty acids composition of tiger nut oil.

\begin{tabular}{ll}
\hline Fatty acid & \% \\
\hline Myristic acid (14:0) & 0.099 \\
Palmitic acid (16:0) & 13.630 \\
Palmitoleic acid (16:1) & 0.255 \\
Heptadecanoic acid (17:0) & 0.0557 \\
Stearic acid (18:0) & 6.776 \\
Oleic acid (18:1) & 69.233 \\
Linoleic acid (18:2) & 8.263 \\
Linolenic acid (18:3) & 0.113 \\
Arachidic acid (20:0) & 0.826 \\
Gadoleic acid (20:1) & 0.172 \\
Behenic acid (22:0) & 0.275 \\
Lignoceric acid (24:0) & 0.303 \\
TSFA* & 21.964 \\
TUSFA** & 78.036 \\
Ratio of TUFA/TSFA & $3.55: 1$ \\
\hline
\end{tabular}

*TSFA: Total saturated fatty acids

**TUSFA: Total unsaturated fatty acids

monounsaturated fatty acids in which oleic acid (18:1) was found to be the dominant fatty acid being $69.23 \%$. On the other hand, palmitic (16:0) was the major saturated fatty acid being $13.63 \%$. In general, total saturated fatty acids in tiger nut oil were $21.96 \%$, while total unsaturated fatty acids were $78.03 \%$. These results agree well with those obtained by Imam et al. (2013), Gambo \& Da'u (2014) and El-Naggar (2016) who found that tiger nut oil had four main fatty acids: linoleic (5.5\%), palmitic (15.4\%), arachidic $(6.1 \%)$ and oleic acid being the most abundant ones (65.8\%). Earlier, Abdel-Nabey (2001) mentioned that the high amount of oleic acid in the tiger nut oil makes it highly valuable healthy oil and thereby can be used as a substitute for olive oil. According to its fatty acid composition, tiger nut oil can be classified in the oleic-linoleic acid group such as olive, sesame, corn, peanut, cotton seed and sunflower seeds. Recently, it is gaining greater importance because of its superior stability and healthy and nutritional benefits. Hence, these results indicate that tiger nut oil can be considered as an edible oil rich in essential fatty acids.

\section{Amino acid composition of DFTF}

The results in Table (5) shows the amino acid composition of DFTF ( $\mathrm{g} / 100 \mathrm{~g}$ protein). The data showed that the major amino acids are glutamic acid, arginine and aspartic acid with the values of $13.76,10.01$ and $9.38 \mathrm{~g} / 100 \mathrm{~g}$ protein, respectively, while the lowest amino acids are cysteine and histidine being 1.56 and $2.19 \mathrm{~g} / 100 \mathrm{~g}$ protein, respectively. The levels of all the essential amino acids except of phenylalanine were found to be higher than those reported by the FAO/WHO (1985). Also, the total essential amino acids $(37.19 \mathrm{~g} / 100 \mathrm{~g}$ protein) were higher than the reported value being $(32.8 \mathrm{~g} / 100 \mathrm{~g})$. It can be concluded that the protein of DFTF can be considered as a good source of essential amino acids compared with the FAO/WHO (1985) reference protein.

Table 5: Amino acid composition of DFTF

\begin{tabular}{llc}
\hline Amino acid & $\mathrm{g} / 100 \mathrm{~g}$ protein & $\begin{array}{c}\text { FAO/WHO } \\
(1985)\end{array}$ \\
\hline Glutamic acid & 13.76 & \\
Arginine & 10.01 & \\
Aspartic acid & 9.38 & 6.6 \\
Leucine * & 7.19 & 3.5 \\
Valine * & 6.88 & 5.8 \\
Lysine * & 5.94 & 3.4 \\
Threonine * & 4.38 & \\
Serine & 3.75 & \\
Alanine & 8.13 & \\
Glycine & 5.32 & 2.8 \\
Isoleucine * & 3.75 & \\
Tyrosine & 2.8 & 6.3 \\
Phenylalanine $*$ & 4.06 & 1.9 \\
Histidine * & 2.19 & \\
Proline & 4.07 & 2.5 \\
Methionine * & 2.8 & \\
Cysteine & 1.56 & \\
Total essential & 37.19 & \\
amino acids & & \\
\hline
\end{tabular}

* Essential amino acids

\section{Sensory evaluation :}

\section{Vegan milk drinks}

The results given in Table (6) for the organoleptic properties of the defatted tiger nut milk drinks show that all the drinks have been generally well accepted by the panelists, being over the numerical value of 7. No significant differences were noted among all tested treatments in all the sensory attributes except for the taste of the control and the odour of the defatted milk drink containing coconut. These formulated drinks can be used as refreshing summer drinks due to their high nutritional value. 
Table 6: Organoleptic evaluation of defatted tiger nut milk drinks with different flavouring agents

\begin{tabular}{lllllc}
\hline \multicolumn{1}{c}{ Treatments } & Colour & Taste & Odour & Texture & Overall acceptability \\
\hline C & $8.40 \pm 0.69^{\mathrm{a}}$ & $7.25 \pm 1.23^{\mathrm{b}}$ & $7.35 \pm 1.33^{\mathrm{b}}$ & $7.40 \pm 1.51^{\mathrm{a}}$ & $7.60 \pm 0.98^{\mathrm{a}}$ \\
$\mathrm{T} 1$ & $8.10 \pm 0.91^{\mathrm{a}}$ & $8.30 \pm 0.91^{\mathrm{a}}$ & $8.45 \pm 0.68^{\mathrm{a}}$ & $8.15 \pm 0.88^{\mathrm{a}}$ & $8.25 \pm 0.64^{\mathrm{a}}$ \\
$\mathrm{T} 2$ & $7.95 \pm 0.60^{\mathrm{a}}$ & $7.85 \pm 0.68^{\mathrm{ab}}$ & $7.70 \pm 0.72^{\mathrm{ab}}$ & $7.35 \pm 1.00^{\mathrm{a}}$ & $7.71 \pm 0.56^{\mathrm{a}}$ \\
T3 & $8.25 \pm 0.79^{\mathrm{a}}$ & $7.55 \pm 1.12^{\mathrm{ab}}$ & $7.95 \pm 0.76^{\mathrm{ab}}$ & $7.40 \pm 1.07^{\mathrm{a}}$ & $7.79 \pm 0.83^{\mathrm{a}}$ \\
T4 & $7.75 \pm 1.03^{\mathrm{a}}$ & $7.6 \pm 1.04^{\mathrm{ab}}$ & $7.80 \pm 1.03^{\mathrm{ab}}$ & $7.60 \pm 0.96^{\mathrm{a}}$ & $7.68 \pm 0.94^{\mathrm{a}}$ \\
T5 & $8.30 \pm 0.95^{\mathrm{a}}$ & $7.55 \pm 1.26^{\mathrm{ab}}$ & $7.45 \pm 1.2^{\mathrm{b}}$ & $7.05 \pm 1.38^{\mathrm{a}}$ & $7.59 \pm 0.97^{\mathrm{a}}$ \\
T6 & $8.20 \pm 0.63^{\mathrm{a}}$ & $8.25 \pm 0.42^{\mathrm{a}}$ & $8.10 \pm 0.74^{\mathrm{ab}}$ & $7.90 \pm 0.74^{\mathrm{a}}$ & $8.11 \pm 0.46^{\mathrm{a}}$ \\
LSD0.05 & 0.73 & 0.88 & 0.85 & 0.99 & 0.71 \\
\hline
\end{tabular}

Means in a column not sharing the same letter are significantly different at $P \leq 0.05$.

C: Control (defatted tiger nut milk drink)

T1: Defatted tiger nut milk drink with cinnamon

T2: Defatted tiger nut milk drink with lemon juice

T3: Defatted tiger nut milk drink with fresh grated ginger

T4: Defatted tiger nut milk drink with vanilla

T5: Defatted tiger nut milk drink with coconut

T6: Defatted tiger nut milk drink with chocolate cocoa

\section{Pudding}

The results of the organoleptic evaluation of the pudding containing different amounts of DFTF are given in Table (7). All the quality attributes except that of the texture of pudding containing 75 and $100 \%$ DFTF were very well accepted by the panelists. The numerical values of the organoleptic attributes decreased with increasing the amount of DFTF. No significant differences have been noted

in the organoleptic attributes between the control sample and the pudding containing 25\% DFTF.

\section{Creamy onion soup}

The results of the organoleptic evaluation of the creamy onion soup containing different amounts of DFTF are presented in Table (8). Generally, all the soups were well accepted by the panelists. The colour, taste, odour, texture and overall acceptabil-

Table 7: Organoleptic evaluation of pudding containing DFTF

\begin{tabular}{lllllc}
\hline \multicolumn{1}{c}{ Treatments } & Colour & \multicolumn{1}{c}{ Taste } & Odour & Texture & Overall acceptability \\
\hline Control & $8.77 \pm 0.83^{\mathrm{a}}$ & $8.77 \pm 0.60^{\mathrm{a}}$ & $8.77 \pm 0.60^{\mathrm{a}}$ & $8.85 \pm 0.37^{\mathrm{a}}$ & $8.89 \pm 0.47^{\mathrm{a}}$ \\
$25 \%$ & $8.27 \pm 0.60^{\mathrm{ab}}$ & $8.50 \pm 0.50^{\mathrm{ab}}$ & $8.58 \pm 0.49^{\mathrm{a}}$ & $8.35 \pm 0.63^{\mathrm{a}}$ & $8.42 \pm 0.48^{\mathrm{a}}$ \\
$50 \%$ & $7.85 \pm 0.55^{\mathrm{bc}}$ & $8.19 \pm 0.63^{\mathrm{bc}}$ & $8.31 \pm 0.48^{\mathrm{ab}}$ & $7.62 \pm 0.96^{\mathrm{b}}$ & $7.99 \pm 0.51^{\mathrm{b}}$ \\
$75 \%$ & $7.38 \pm 0.65^{\mathrm{cd}}$ & $7.69 \pm 0.75^{\mathrm{cd}}$ & $7.92 \pm 0.95^{\mathrm{bc}}$ & $6.88 \pm 0.71^{\mathrm{c}}$ & $7.47 \pm 0.58^{\mathrm{c}}$ \\
$100 \%$ & $7.08 \pm 0.86^{\mathrm{d}}$ & $7.50 \pm 0.82^{\mathrm{d}}$ & $7.77 \pm 0.60^{\mathrm{c}}$ & $6.50 \pm 0.70^{\mathrm{c}}$ & $7.21 \pm 0.57^{\mathrm{c}}$ \\
LSD & 0.56 & 0.52 & 0.51 & 0.55 & 0.41 \\
\hline
\end{tabular}

*Means in a column not sharing the same letter are significantly different at $P \leq 0.05$.

Table 8: Organoleptic evaluation of creamy onion soup containing DFTF

\begin{tabular}{llllll}
\hline \multicolumn{1}{c}{ Treatments } & \multicolumn{1}{c}{ Colour } & \multicolumn{1}{c}{ Taste } & \multicolumn{1}{c}{ Odour } & \multicolumn{1}{c}{ Texture } & Overall acceptability \\
\hline Control & $8.57 \pm 0.53^{\mathrm{a}}$ & $8.43 \pm 0.53^{\mathrm{a}}$ & $8.14 \pm 0.69^{\mathrm{a}}$ & $8.42 \pm 0.53^{\mathrm{a}}$ & $8.39 \pm 0.48^{\mathrm{a}}$ \\
$25 \%$ & $7.86 \pm 0.89^{\mathrm{ab}}$ & $8.42 \pm 0.53^{\mathrm{a}}$ & $7.79 \pm 0.70^{\mathrm{a}}$ & $8.29 \pm 0.76^{\mathrm{ab}}$ & $8.09 \pm 0.51^{\mathrm{ab}}$ \\
$50 \%$ & $7.29 \pm 0.76^{\mathrm{b}}$ & $8.14 \pm 0.69^{\mathrm{a}}$ & $7.21 \pm 0.70^{\mathrm{a}}$ & $8.08 \pm 0.82^{\mathrm{ab}}$ & $7.59 \pm 0.37 \mathrm{~b}$ \\
$75 \%$ & $7.00 \pm 0.82^{\mathrm{b}}$ & $7.7 \pm 0.95^{\mathrm{a}}$ & $7.86 \pm 0.69^{\mathrm{a}}$ & $7.71 \pm 0.76^{\mathrm{ab}}$ & $7.64 \pm 0.50^{\mathrm{b}}$ \\
$100 \%$ & $7.00 \pm 1.15^{\mathrm{b}}$ & $7.7 \pm 0.95^{\mathrm{a}}$ & $7.43 \pm 1.27^{\mathrm{a}}$ & $7.57 \pm 0.98^{\mathrm{b}}$ & $7.43 \pm 0.89^{\mathrm{b}}$ \\
LSD & 0.93 & 0.83 & 0.92 & 0.85 & 0.63 \\
\hline
\end{tabular}

* Means in a column not sharing the same letter are significantly different at $P \leq 0.05$. 
ity of all the soup samples were over the numerical value of 7.0 (like moderately).

No significant differences could be traced among all the treatments in taste, odour and texture except the texture of the soup containing $100 \%$ DTF. Also, no significant differences could be noted between the control and the creamy onion soup containing $25 \%$ DFTF in all the studied attributes and no significant differences were noted among all the soup samples containing DFTF.

\section{CONCLUSION}

The FFTF is a rich source for oil and oleic acid being the dominant fatty acid in this oil. Therefore, it can be considered as a good source for healthy vegetable oil. The DFTF had a high nutritive value due to its content of nitrogen free extract, starch, dietary fiber, total and non-reducing sugars, certain elements and fairly good essential amino acid composition. Consequently, DFTF can be considered as a suitable by-product for different food applications. In the present study, DFTF has been used in preparing some food products which were found highly acceptable by the panelists. Finally, based on the results of the present study, increasing the cultivated area of tiger nut tubers as a source of healthy vegetable oil and using its DFTF for preparing some food products, is very important and recommended.

\section{REFERENCES}

Abdel-Hady, E.Y. 1998. Enzymatic Production of High Protein Rice Flour from Egyptian Broken Rice: Chemical, Physical, Nutritional and Technological Studies". PhD. Thesis, Department of Food Science and Technology Faculty of Agriculture, Alexandria University, Egypt.

Abdel-Nabey, A. A. 2001. Chemical and Technological Studies on chufa (tiger nut) tubers (Cyperus esculentus L.), Alexandria Journal of Agricultural Research, 46:71-80.

Adejuyitan, J.A., Otunola, E.T., Akande, E.A., Bolarinwa, I.F.\& Oladokun, F.M. 2009. Some physicochemical properties of flour obtained from fermentation of tiger nut (Cyperus esculentus) sourced from a market in Ogbomoso, Nigeria. African Journal of Food Science, 3:51-5.

Aditya, J. 2012. Functional Properties of Select Seed Flours and Blackgram (Phaseolus Mungo L.)
Storage Globulin Protein Gene Identification. M. Sc. Thesis, Dep. of Science, Florida State University Libraries.

Anderson, J.W., Baird, P., Davis, R.H., Ferreri, S., Knudtson, M. \& Koraym, A. 2009. Health benefits of dietary fiber. Nutrition Reviews, 67:188-205.

Anon. 2013. Tiger nuts for Healthy Eating. [www. tiger nuts. com]. Accessed May 17.

Alegría-Torán, A. \& Farré-Rovira R. 2003. Horchata y salud: Aspectos nutricionales y dietéticos. In: Fundación Valenciana de Estudios Avanzados, editor. Jornada Chufa y Horchata: Tradición y Salud. Valencia, Spain: Consellería de Agrit cultura, Pesca y Alimentación.. pp. 55-70.

AOAC. 2005. Official Method of Analysis. 17thed. Association of Official Analytical Chemists, Gaithersburg Maryl, U.S.A.

Belewu, M.A. \& Belewu, K.Y. 2007. Comparative physico-chemical evaluation of tiger-nut, soybean and coconut milk sources. International Journal of Agricultural and Biology, 9: 785-787.

Borges, O., Gonçalves, B., Sgeoeiro, L., Correia, P. \& Silva, A. 2008. Nutritional quality of chestnut cultivars from Portugal. Food Chemistry, 106:976-84.

Cantalejo, M.J. 1997. Analysis of volatile components derived from raw and roasted earthalmond (Cyperus esculentus L.). Journal of Agricultural and Food Chemistry, 45:18531860.

Chevallier,A. 1996.The Encyclopedia of Medicinal Plants. Dorling Kindersley. London. International Standard Book Number. 9: 980751303148.

Chopra, R.N., Nayar, S.L. \& Chopra, I.C. 1986. Glossary of Indian medicinal plants (Including the supplement). Council of Scientific and Industrial Research, New Delhi. pp. 18-30.

Chukwuma, E.R., Obioma, N. \& Cristopher, O.I. 2010. The phytochemical composition and some biochemical effects of Nigerian tiger nut (Cyperus esculentus L.) tuber. Pakistan Journal of Nutrition 9:709-15.

Cortés, C., Esteve, M.J., Frígola, A.\& Torregrosa, F. 2005. Quality characteristics of horchata (Spanish vegetable beverage) treated with pulsed electric fields during shelf-life. Food Chemistry, 91:319-25. 
Corrales, M., de Souza, P.M., Stahl, M.R. \& FernÂne dez, A. 2012. Effects of the decontamination of a fresh tiger nuts'milk beverage (horchata) with short-wave ultraviolet treatments (UVC) on quality attributes. Innovative Food Science and Emerging Technologies, 43:163-8.

Coskuner, Y., Ercan, R., Karababa, E. \& Nazlican, A.N. 2002. Physical and chemical properties of chufa (Cyperus esculentus L) tubers grown in the çukurova region of Turkey. Journal of the Science of Food and Agriculture, 82:625-31.

CRDO. 2012 Consejo Regulador de la Denominación de Origen Chufa de Valencia.Available from: http://www.chufadevalencia.org. Accessed Jan 3, 2012.

Ejoh, D.R., \& Ndjouenkeu, R. 2007. Soaking behavior and milky extraction performance of tiger nut (Cyperus esculentus) tubers. Journal of Food Engineering, 78: 546-550.

El-Naggar, E.A. 2016. Physicochemical characteristics of tiger nut tuber (Cyperus esculentus), oil. Middle East. Journal of Applied Sciences, 6:1003- 1011.

FAO/WHO. 1985. Energy and Protein Requirement, Geneva. Report of a joint FAO/WHO/ UNU expert consultation. WHO Technical Report Series No. 724.

Farag, R.S., Abdel Rahim, E.A., Elsharabasy, A.M., Hewedy, F.M. \& Ragab, A.A. 1984. Biochemical studies on lipids of hens egg during incubation. Seifen, Oele, Fette, Wachse deFette, Wachse, 100: 63.

Fernández-López, J., Sendra, E., Sayas-Barberá, E., Navarro, C. \& Pérez-Alvarez, J. A. 2008. Physico-chemical and microbiological profiles of "salchichón" (Spanish dry-fermented sausage) enriched with orange fiber. Meat science, 80: 410-417.

Gambo, A. \& Da'u, A. 2014. Tiger nut (Cyperus esculentus): Composition, products, uses and health benefits - a review. Bayero Journal of Pure and Applied Sciences, 7: 56 - 61.

Imam, T.S., F.G. Aliyu, \& Umar, H.F. 2013. Preliminary phytochemical screening, elemental and proximate composition of two varieties of Cyperus esculentus (Tiger nut). Nigerian Journal of Basic and Applied Science. 21: $247-251$.
Kramer, A. \& Twigg, B.A. 1973. Quality Control for the Food Industry 3th Ed. AVI puplishing Co. Westport Conn. London, England.

Ku, C. S. \& Mun, S. P. 2008 Optimization of the extraction of anthocyanin from Bokbunja (Rubus Coreanus Miq.) marc produced during traditional wine processing and characterization of the extracts. Bioresource Technology, 99: 8325-8330.

Linssen, J.P.H., Kielman, G.M., Cozijnsen, JL \& Pilnik W. 1988. Comparison of chufa and olive oils. Food Chemistry, 28:279-85.

Mosquera, L.A., Sims, C.A., Bates, R.P \& Ó Keefe, S.F. 1996. Flavour and stability of horchata de chufas. Journal of Food Science, 61: 856861.

Narayana, K.\& Narasinga, R.M.S. 1992. Functional properties of raw and heat processed winged bean flour. Journal of Food Science, 47: 1534-1538.

Oladele, A. K. \& Aina, J.O. 2007. Chemical composition and functional properties of flour produced from two varieties of tiger nut ( $C y$ perus esculentus). African Journal of Biotechnology, 6: 2473-2476.

Olagunju, A.O., 2006. Extraction and Characterization of Oil from Tiger Nut Seed (Cyperus esculentus) Using $2^{3}$ Full Factorial Design. M. Sc. Thesis, Dep. of Chemical Engineering, Federal Univ. of Technology, Minna, Niger State, Nigeria.

Omode, A. O., Fatoki, O. \& Olaogun, K. A. 1995. Physicochemical properties of some underutilized and non conventional oil seed. Journal of Agricultural and Food Chemistry, 11:5053.

Prosky, L., Asp, N. G., Furda, I., DeVries, J. W., Schweizer, T. F. \& Harland, B. F. 1985. Determination of dietary fibre in foods and food products: Collaborative study. Journal Association of Official Analytical Chemists, 68: 677-679.

Raymond, B. \& James, D.D. 1970. Soup Manufacture, Canning, Dehydration \& Quick-Freezing. Food Trade Press LTD. Book Third Edition PP: 65

SAS 2004. SAS Institute Inc. SAS/ETS ${ }^{\circledR} 9.1$ User'SAS Institute Inc. 2004. User's Guide. Cary, NC. 
Sathe, S. K.\& Salunkhe, D. K. 1981. Functional properties of the great Northern bean (Phaseolus vulgaris L.) proteins: emulsion, foaming, viscosity and gelation properties. Journal of Food Science, 46, 71-74.

Stahle, E., 1967. Thin Layer Chromatography. A Laboratory Handbook. Ed, Springer Verloag Berline, Heidel Berg, New York pp: 35.
Sze-Tao, K. W. C. \& Sathe, S. K. 2000. Functional properties and in vitro digestibility of almond (Prunus dulcis L.) protein isolate. Food Chemistry, 69: 153-160.

Temple, V.J., Ojebe, T.O. \& Kapu, M.M. 1989. Chemical analysis of tiger nut (Cyperus esculentis). Journal of the Science of Food and Agriculture, 49:261-2.

\title{
تقييه واستخل ام دقيق حب المزيز منزوع الدهن فى تخضير بعض المشروبات والمنتجات الغذائية
}

\author{
رضا عبد الحكيم عامر \\ قسم بحوث تصنيع الحاصلات البستانية - معهد بحوث تكنولوجيا الاغذية \\ مركز البحوث الزراعية - مصر
}

تم دراسة التركيب الكيماوي وبعض الخواص الطبيعية والوظيفية وكذلك محتوى المعادن لدقيق درنات

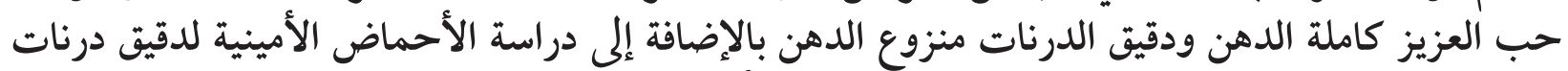

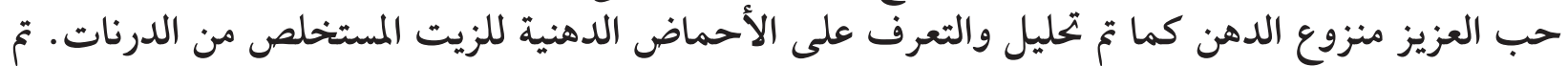

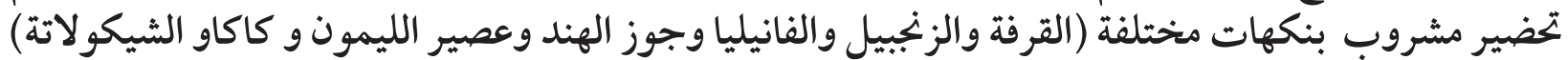

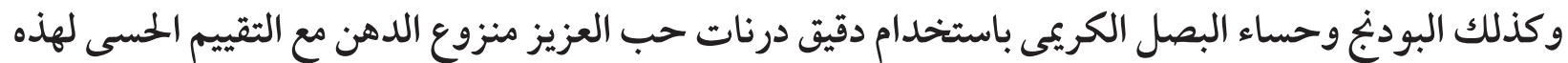

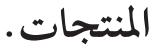

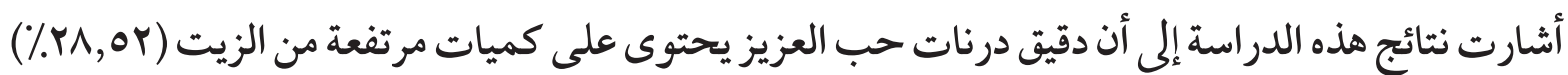

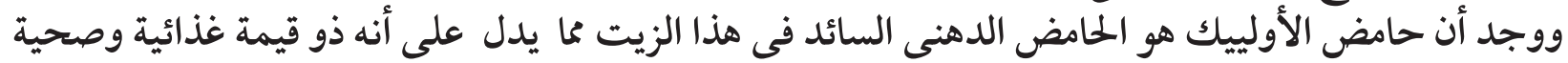

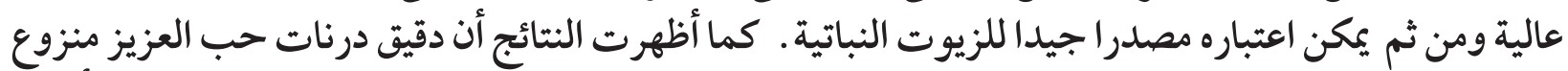

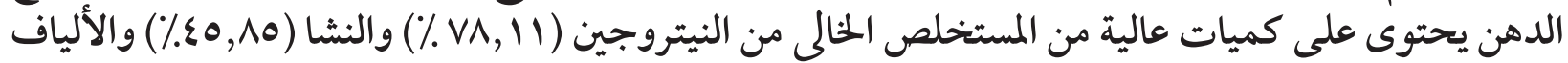

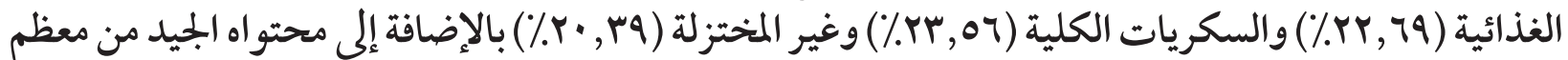

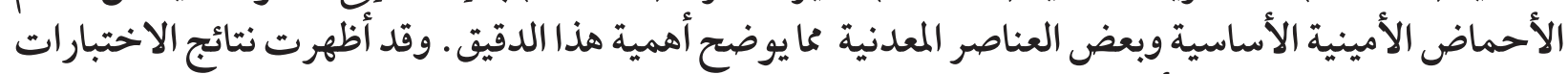

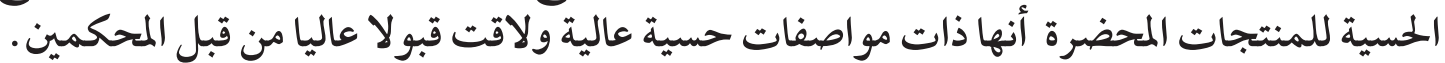

